\title{
The Effect of Inbreeding on Early Growth of Acacia mangium in Vietnam
}

\author{
By C. E. Harwood ${ }^{1}$, Ha Huy Thinh ${ }^{2}$, Tran Ho Quang ${ }^{2}$, P. A. Butcher ${ }^{1}$ and E. R. Williams ${ }^{1}$
}

(Received 23 $3^{\text {rd }}$ February 2004)

\begin{abstract}
Seeds were collected from each of twelve parent trees from each of six seed orchards of Acacia mangium in different locations in Vietnam to examine the relationship between growth and inbreeding in this species. Seedlings were raised and planted out in a field trial at $\mathrm{Ba} \mathrm{Vi}$ in northern Vietnam. The inbreeding status (self-fertilized or outcrossed) of most of the seedlings was determined by DNA analysis. Heights were measured at 12 and 18 months, and diameter at breast height (dbh) at 18 months. There were significant differences in growth between the six orchard sources at 18 months. Progeny from two orchards based primarily on Papua New Guinea (PNG) provenances with high levels of outcrossing displayed the best growth, with mean heights of $3.1 \mathrm{~m}$ at 18 months, while an orchard also based primarily on PNG provenances but with predominantly selfed progeny, and another orchard based on Queensland provenances with 51\% selfed progeny, displayed the poorest growth (mean heights of $2.0 \mathrm{~m}$ and $2.2 \mathrm{~m}$ respectively). Analysis of variance established that within the 32 families that included both selfed and outcrossed individuals, self-fertilized individuals were significantly $(P<0.001)$ slowergrowing than were outcrossed individuals, with selfs on average $15 \%$ smaller in mean height and $16 \%$ smaller in mean dbh at age 18 months, relative to outcrosses. The results demonstrate the need to minimise selfing in operational seed production for A. mangium plantations.
\end{abstract}

Key words: Seed orchards, self, outcross, growth, inbreeding depression, Acacia mangium.

\section{Introduction}

Acacia mangium Willd. is a fast-growing tropical tree species now widely planted for pulpwood production, with over 1 million ha planted in tropical countries worldwide (TURNBULL $e t$ al., 1998).

Consistent differences in growth performance among natural provenances of $A$. mangium have been demonstrated in many trials across a number of countries (HARWOOD and WilliaMs, 1992; Turvey, 1996; Nirsatmanto et al., 2003). Provenances from the south west of Western Province, Papua New Guinea (PNG), and adjacent Western Papua display the fastest growth, followed by Claudie River from far north Queensland $\left(13^{\circ} \mathrm{S}\right)$ and then provenances from further south in Queensland $\left(16-18^{\circ} \mathrm{S}\right)$, with outlying provenances from the Indonesian island of Ceram, and Piru in Western Papua, growing the slowest.

Acacia mangium has been shown to have variable levels of within-population genetic diversity (BUTCHER et al., 1998), and variation in outcrossing rates (BUTCHER et al., 1999), across its natural range. An investigation of outcrossing rates using microsatellite markers on seedling progenies showed that populations from the core of the species' distribution in PNG with the highest levels of genetic diversity (BUTCHER et al., 1998) were completely outcrossing, the Claudie River provenance

\footnotetext{
1) CSIRO Forestry and Forest Products, PO Box E4008, Kingston ACT 2604, Australia.

2) Research Centre for Forest Tree Improvement, Forest Science Institute of Vietnam, Chem, Tu Liem, Hanoi, Vietnam.
}

from north Queensland (latitude $13^{\circ} \mathrm{S}$ ) displayed slightly lower genetic diversity and $80 \%$ outcrossing, while the southernmost populations in Queensland, at latitudes $15-18^{\circ} \mathrm{S}$, with less than half the genetic diversity of PNG, had low ( 30\%) outcrossing rates (BUTCHER et al., 1999). A seed production area at Subanjeriji in southern Sumatra, with $56 \%$ of the genetic diversity of PNG provenances, displayed an average outcrossing rate of around $30 \%$, consistent with outcrossing rates in the Queensland populations from where the seed was sourced (BUTCHER et al., 1999).

Initial introductions of A. mangium to South East Asia, commencing in the 1960s, were from a narrow genetic base. Starting from small stands deriving from a collection from a single parent tree from a natural $A$. mangium provenance at Mission Beach, Queensland, several generations of plantations were raised in Sabah. The resultant inbreeding led to declining seedling vigour in the nursery when seedlots from successive generations were compared (SIM, 1984). Similarly, the first seed stands in Subanjeriji, South Sumatra, that were used to establish many of the early Indonesian plantations were established from a limited seed collection from southern Queensland provenances. Seedlings from the Subanjeriji seed stands performed poorly in plantations and field trials compared to those from natural populations in Papua New Guinea (PNG) (TURVEY, 1996).

Inbreeding, with self-fertilization as its extreme manifestation, is well known to result in depression of growth in many tree genera, for example coniferous genera (WILLIAMS and Savolainen, 1996), Betula (WANG et al., 1999) and Eucalyptus (ELDRIDGE et al., 1993). Depression of growth in self-fertilized seedlings was demonstrated for the temperate zone Acacia species A. dealbata and A. mearnsii (Moffat and Nixon, 1974). It is therefore of interest to determine the level of inbreeding depression in A. mangium and whether this is consistent across provenances, given the between-provenance variation in genetic diversity and outcrossing rates demonstrated in this species. Controlled pollination of acacias to produce selfed and outcrossed progeny for comparative trials is technically very difficult (SEDGLEY and HARBARD, 1993). However, the inbreeding status of individual genotypes in open-pollinated progenies can now be determined using highly variable DNA markers (Butcher et al., 1999, 2002).

This paper reports on the field performance of outcrossed and selfed seedlings raised from seed collected in six open-pollinated seed orchards of A. mangium in Vietnam. The orchards were established from different natural provenances. The study on seedling performance reported here was linked to an investigation by BUTCHER et al., (2002) that estimated outcrossing rates in the different seed orchards based on segregation of alleles in progeny arrays using microsatellite markers.

\section{Materials and Methods}

The locations of the six seed orchards that were sampled for the trial, and the seed sources used to establish these orchards, are listed in Table 1. The Ba Vi Fortip orchard had been developed by selective thinning of a progeny trial testing 90 openpollinated progenies, while the other five orchards were seed 
production areas developed by selective thinning of plantations established from unpedigreed bulk seedlots, of known naturalprovenance origin except the Ham Yen orchard which was established from Queensland provenances of unknown origin. All but the two youngest stands (Ba Vi Fortip and Dong Ha) have been used as seed sources for operational planting of $A$. mangium in Vietnam, and for convenience all are referred to as "orchards".

Table 1. - Seed orchards in Vietnam that provided seed for the study.

\begin{tabular}{|c|c|c|c|c|c|c|}
\hline $\begin{array}{l}\text { Seed } \\
\text { Orchard }\end{array}$ & Code & $\begin{array}{l}\text { Latitude } \\
\left({ }^{\circ} \mathrm{N}\right)\end{array}$ & $\begin{array}{l}\text { Long- } \\
\text { itude } \\
\left({ }^{\circ} \mathrm{E}\right)\end{array}$ & $\begin{array}{l}\text { Seed source used to } \\
\text { establish orchard }\end{array}$ & $\begin{array}{l}\text { Age } \\
\text { (y) in } \\
2002\end{array}$ & $\begin{array}{l}\text { Estimated out- } \\
\text { crossing rate }^{\mathrm{C}}\end{array}$ \\
\hline Bau Bang & BB & $11^{\circ} 15^{\prime}$ & $106^{\circ} 38^{\prime}$ & Daintree (Qld) & 12 & 0.49 \\
\hline Ba Vi Fortip & $\mathrm{BF}$ & $21^{\circ} 08^{\prime}$ & $105^{\circ} 28^{\prime}$ & $\begin{array}{l}70 \% \text { from } \mathrm{PNG} \text { and } \\
30 \% \text { from } \mathrm{Qld}^{\mathrm{B}}\end{array}$ & 4 & 0.13 \\
\hline $\begin{array}{l}\text { Ba Vi } \\
\text { Pongaki }\end{array}$ & $\mathrm{BP}$ & $21^{\circ} 10^{\prime}$ & $105^{\circ} 20^{\prime}$ & Pongaki (PNG) & 8 & 0.90 \\
\hline Dong $\mathrm{Ha}$ & DH & $16^{\circ} 47^{\prime}$ & $107^{\circ} 03^{\prime}$ & $\begin{array}{l}70 \% \text { from } \mathrm{PNG} \text { and } \\
30 \% \text { from } \mathrm{Old}^{\mathrm{B}}\end{array}$ & 5 & 1.00 \\
\hline Ham Yen ${ }^{A}$ & $\mathrm{HY}$ & $22^{\circ} 02^{\prime}$ & $106^{\circ} 02^{\prime}$ & $\mathrm{Qld}^{\mathrm{A}}$ & 14 & 0.93 \\
\hline Phong Chau & $\mathrm{PC}$ & $21^{\circ} 30^{\prime}$ & $105^{\circ} 13^{\prime}$ & Cardwell (Qld) & $>10$ & 0.92 \\
\hline
\end{tabular}

A The seed sources used to establish this seed orchard were from Queensland (Qld) but the actual provenances are not known.

в The Queensland provenance used was Claudie River.

C Proportion of outcrossed progeny detected using six microsatellite loci.

A minimum of 20 seed pods per tree were collected from each of twelve trees within each of the six orchards, except Ba Vi Fortip where only ten trees were sampled. Seedling families (i.e. progenies raised from individual mother trees) were raised in a nursery at the Forest Science Institute of Vietnam in Hanoi. Orchard, tree and pod identities of all seedlings were retained. Seeds were sown into individual polythene bags filled with a potting mix of sieved clay-loam soil. Leaves were sampled from one seedling from each of 12 pods per family to extract DNA for the study of outcrossing rates reported by BUTCHER et al. (2002). To determine whether progeny were outcrossed or selfed, they were genotyped, together with the mother, using six microsatellite loci; Am018, Am041, Am164, Am173, Am387 and Am465, following procedures in BUTCHER et al. (2000). Outcrossed progeny contained an allele not present in the mother. The seedlings were grown on for planting out in field trials. There were some deaths in the nursery, and it was noted that the seedlings from the Bau Bang and Ba Vi Fortip orchards grew substantially slower than those from the other orchards.

The primary objective of the field trials was to compare the field performance of outcrossed and selfed plants that were identified in the study by BuTCHER et al. (2002). At the time of trial planting, the outcrossing/selfing status of individual plants had not been determined. It was anticipated that molecular genetic analysis would identify selfed and outcrossed genotypes within many families in several of the seed orchards. A secondary objective was to compare the performance of progeny from the different orchards, to help identify the best orchard seed sources for operational plantations.

The field trial was located at $\mathrm{Ba} \mathrm{Vi}$, in $\mathrm{Ha}$ Tay province, northern Vietnam (latitude $21^{\circ} 08^{\prime} \mathrm{N}$, longitude $105^{\circ} 28^{\prime} \mathrm{E}$, altitude 50 metres). Mean annual rainfall is $1650 \mathrm{~mm}$ with a summer maximum and a pronounced dry period from December to April inclusive. The soil at the trial site was a shallow, infertile ferallitic clay loam derived from schist parent material, with a surface $\mathrm{pH}$ of 4.0. It had previously been occupied by a Eucalyptus camaldulensis plantation. Before planting, the site was completely cleared, and planting rows were ripped to a depth of $30 \mathrm{~cm}$ with a tracked bulldozer fitted with a single-tined ripper.
The trial tested 864 seedlings (nominally 6 orchards $\mathrm{x} 12$ families x 12 seedlings per family). A split-plot design was used, with the seedlings of individual families grouped together in 12 -tree sub-plots ( 2 rows $\mathrm{x} 6$ seedlings), to minimise environmental variation in the growing environment of the plants within each family. Spacing was $4 \mathrm{~m}$ between planting rows and $2.5 \mathrm{~m}$ between seedlings along the rows. Families from each orchard were grouped into two main plots each of six families. Each main plot was contiguous (6 rows x 24 trees). To enable statistical comparison of the performance of the different orchards, the main plots were laid out in two replicates, each replicate containing one 6 -family main plot from each of the 6 orchards, in a randomised complete block design. Slight adjustments had to be made to the design because there were only ten families from Ba Vi Fortip: additional seedlings from families Ba Vi Fortip 9 and Ba Vi Fortip 10 were substituted for the unavailable families. The individual orchard, mother tree and pod identity of every seedling in the designed experiment was retained. The entire trial was surrounded by two external buffer rows of surplus A. mangium seedlings from the 6 orchards.

The trial was planted in October 2001. A 40 × 40 × $40 \mathrm{~cm}$ planting hole was cultivated for each seedling, and $200 \mathrm{~g}$ of NPK chemical fertiliser worked into the cultivated soil before planting. Intensive manual weed control was maintained for the first two years after planting, with ring weeding to a diameter of $1 \mathrm{~m}$ around all seedlings every 3-6 months as required. Individual tree heights were measured to the nearest $0.1 \mathrm{~m}$ using height poles, at 12 months and 18 months after planting. Diameter at breast height, $1.3 \mathrm{~m}(\mathrm{dbh})$ was measured to the nearest $0.1 \mathrm{~cm}$ at 18 months using diameter tapes.

\section{Outcrossing status of seedlings}

The outcrossing status of each seedling in the field trial (whether outcrossed, selfed or unknown) was assigned from the genetic analysis summarised by BUTCHER et al. 2002). A. mangium pollen is produced in polyads containing 16 pollen grains, so in most instances all individuals within a pod will have the same male parent, as it is physically difficult for two different polyads to lodge onto a stigma and both contribute pollen germ cells to a flower. A study of correlated paternity in A. melanoxylon, which has a similar reproductive system to $A$. mangium, revealed that $90 \%$ of pods contained seeds derived from a single polyad (MUONA et al., 1991).

The status of $773(89.5 \%)$ of the seedlings in the trial was known unambiguously because it had been determined by DNA analysis. The status of $73(8.4 \%)$ of the seedlings was inferred. These were seedlings that were not genotyped, but which were from pods from which another seedling had been genotyped. A further 15 seedlings came from pods where no individual had been typed, so their outcrossing status was unknown. It was necessary to exclude from all analyses three individuals that were shown by DNA genotyping not to belong to their designated family, indicating labelling errors at some stage in the experiment.

\section{Statistical analysis}

Analyses were conducted to display different aspects of the growth performance of the seedlings. Variates analysed were height at 12 and 18 months, and dbh at 18 months.

A comparison of the different orchards was first obtained using a non-orthogonal analysis of variance, with replicates and orchards declared as fixed effects in that order. This analysis used the mean square associated with the main plots as the error term for testing the significance of differences among 
orchards. This analysis included the data from the 15 seedlings of unknown outcrossing status. A different set of six randomly chosen families of each orchard was used in each of the two replicates, so replicate effects were confounded with family differences between the two sets of families per orchard.

As is evident from Table 1, the proportion of selfed and outcrossed seedlings was strongly confounded with orchard identity. Dong Ha was fully outcrossing, Ba Vi Pongaki, Phong Chau and Ham Yen predominantly outcrossing, Ba Vi Fortip predominantly selfing and Bau Bang produced self-fertilized and outcrossed seedlings in approximately equal proportions.

To estimate the mean performance of selfed and outcrossed seedlings within each orchard, a second analysis used a mixed model with orchard, outcrossing status and their interaction as fixed effects, and family as a random effect. This analysis excluded the 15 seedlings of unknown crossing status, and combined the remaining seedlings into two crossing types: outcrossed (definitely outcrossed + probably outcrossed) and selfed (definitely selfed + probably selfed).

To focus more precisely on the impact of selfing after removing as far as possible the confounding with genetic background, a third analysis excluded those families that comprised entirely selfed or outcrossed individuals. It was confined to families having both selfed and outcrossed seedlings; a total of 32 families across five of the orchards. A fixed effects model was used, with factors fitted in the following order: family, outcrossing status and the interaction term family.outcrossing status.

\section{Results}

Survival to age 18 months after planting was excellent, at $92.6 \%$, and was not subjected to statistical analysis.

Mean heights at 12 and 18 months and dbh at 18 months for the different orchards from the first analysis are shown in Table 2. The $F$-probability for the comparison between orchards, based on the variance ratio of the orchard mean square to the main plots mean square, just fails to achieve the conventional significance level $(P<0.05)$ for height at 12 and 18 months, but is significant $(P<0.05)$ for dbh at 18 months. The statistical test to compare orchards was of low power, being based on only five degrees of freedom in the numerator and denominator of the $F$-ratio. The two orchards based on PNG provenances with high levels of outcrossing ( $\mathrm{Ba}$ Vi Pongaki and Dong $\mathrm{Ha}$ ) displayed the best growth, with mean heights of over $3 \mathrm{~m}$ at 18 months, the two based on Queensland provenances with high levels of outcrossing (Ham Yen and Phong Chau) were intermediate, while Bau Bang, based on Queensland provenances and with $49 \%$ outcrossing, and Ba Vi Fortip, based on PNG provenances and with $13 \%$ outcrossing, were slowest-growing with mean heights of only $2.22 \mathrm{~m}$ and $2.04 \mathrm{~m}$ at 18 months, respectively.

Table 2. - Orchard means for height at 12 and 18 months and dbh at 18 months (all trees included).

\begin{tabular}{lccc}
\multicolumn{1}{c}{ Orchard } & $\begin{array}{c}\text { Height }(\mathrm{m}) \\
12 \text { months }\end{array}$ & $\begin{array}{c}\text { Height }(\mathrm{m}) \\
18 \text { months }\end{array}$ & $\begin{array}{c}\text { Dbh }(\mathrm{cm}) \\
18 \text { months }\end{array}$ \\
\hline Bau Bang & 1.74 & 2.22 & 1.96 \\
Ba Vi Fortip & 1.61 & 2.04 & 2.06 \\
Ba Vi Pongaki & 2.37 & 3.06 & 2.78 \\
Dong Ha & 2.36 & 3.07 & 2.69 \\
Ham Yen & 1.85 & 2.47 & 2.28 \\
Phong Chau & 2.04 & 2.61 & 2.31 \\
$\quad F$-prob.* & 0.06 (n.s.) & 0.06 (n.s.) & $0.03(\mathrm{P}<.05)$ \\
\hline
\end{tabular}

$* F$-probability of differences between orchards based on ratio of orchard mean square to main plots mean square, with 5 degrees of freedom for both numerator and denominator. n.s. = not significant, $P<0.05=$ $F$-probability $<0.05$.
Mean height and dbh at 18 months of selfed and outcrossed trees in each orchard, estimated from the second analysis, are shown in Figures 1 and 2 (the inferred selfs and outcrosses are included). The number of selfed and outcrossed trees in each orchard is also shown. This analysis indicated significant differences between families within orchards. The variance component for families (fitted as a random effect) was at least three times as large as its standard error for height at 12 and 18 months and diameter at 18 months.

The third analysis of variance, focusing on the effect of outcrossing status only in those families having both selfed and outcrossed progeny, is shown in Table 3.

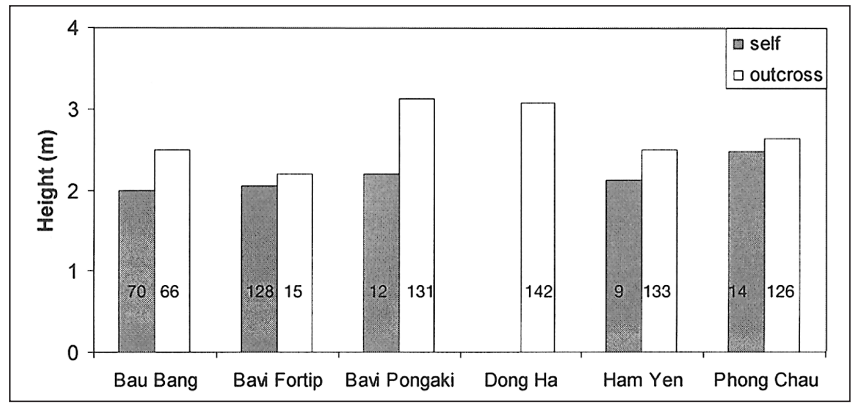

Figure 1. - Mean height (m) of selfed and outcrossed trees from each orchard at 18 months after planting, showing numbers of individuals in each category.

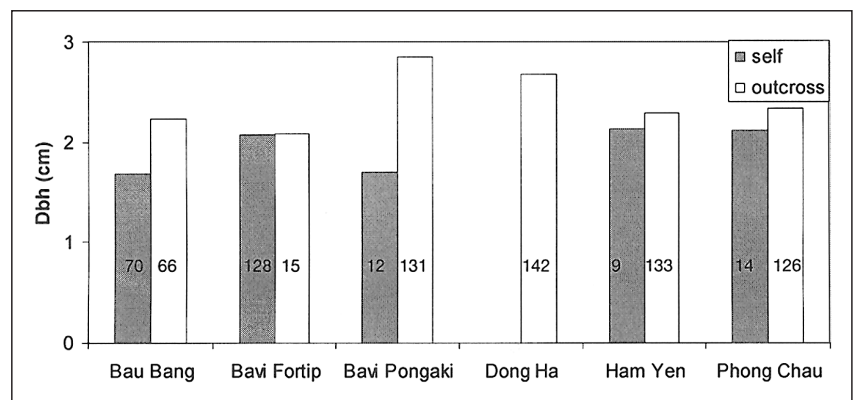

Figure 2. - Mean diameter at breast height $(\mathrm{cm})$ of selfed and outcrossed trees from each orchard at 18 months after planting, showing numbers of individuals in each category.

Table 3. - Analysis of variance for interaction of family and outcrossing status, for 32 families having both selfed and outcrossed seedlings.

\begin{tabular}{lrrrrr}
\hline Height at 12 months & & & & & \\
& d.f. & s.s. & m.s. & v.r. & F pr. \\
family & 31 & 48.1194 & 1.5522 & 5.66 & $<.001$ \\
cross type & 1 & 2.8820 & 2.8820 & 10.51 & 0.001 \\
family.cross type & 31 & 9.7648 & 0.3150 & 1.15 & 0.274 \\
Residual & 300 & 82.2752 & 0.2743 & & \\
Height at 18 months & & & & & \\
& d.f. & S.s. & m.s. & v.r. & F pr. \\
family & 31 & 88.8043 & 2.8647 & 7.63 & $<.001$ \\
cross type & 1 & 5.9771 & 5.9771 & 15.91 & $<.001$ \\
family.cross type & 31 & 10.9766 & 0.3541 & 0.94 & 0.558 \\
Residual & 301 & 113.0548 & 0.3756 & & \\
& & & & & \\
Dbh at 18 months & & & & & \\
& d.f. & S.s. & m.s. & v.r. & F pr. \\
family & 31 & 66.9197 & 2.1587 & 5.04 & $<.001$ \\
cross type & 1 & 6.2829 & 6.2829 & 14.66 & $<.001$ \\
family.cross type & 31 & 13.9572 & 0.4502 & 1.05 & 0.399 \\
Residual & 301 & 129.0429 & 0.4287 & & \\
\hline
\end{tabular}

Note: d.f. $=$ degrees of freedom, s.s. $=$ sum of squares, m.s. = mean square, v.r. $=$ variance ratio an $F$ pr. $=F$-probability. 
The effect of crossing status was significant $(P<0.001)$ for all three variates, while the interaction between family and crossing status was not significant. This analysis provided estimates for mean performance of selfed and outcrossed seedlings across the 32 families, as shown in Table 4.

Table 4. - Estimated mean growth of outcrossed and selfed seedlings across the 32 families examined in Table 3.

\begin{tabular}{lccc} 
& $\begin{array}{c}\text { Mean of selfed } \\
\text { individuals }\end{array}$ & $\begin{array}{c}\text { Mean of outcrossed } \\
\text { individuals }\end{array}$ & $\begin{array}{c}\text { Standard error of } \\
\text { difference of means }\end{array}$ \\
\hline Height, 12 months (m) & 1.64 & 1.90 & 0.07 \\
Height, 18 months (m) & 2.09 & 2.46 & 0.09 \\
Dbh, 18 months (cm) & 1.90 & 2.27 & 0.09
\end{tabular}

\section{Discussion}

The results of the field trial confirm that selfing leads to a marked reduction in the early growth of $A$. mangium. Given the limitations of the trial, which was planted before the crossing status of individual trees was known, the best direct estimate of the impact of selfing is obtained from the analysis restricted to those 32 families having both selfed and outcrossed individuals. From this analysis (Table 4) selfing resulted in a significant reduction of $15 \%$ in mean height and $16 \%$ in mean dbh at age 18 months. This conclusion is based on 32 maternal genotypes across five orchards, and a larger number of paternal genotypes. The lack of significance of the family-bycrossing status interaction also supported the generality of inbreeding depression of growth in A. mangium. This selfing versus outcrossing information is derived from mother trees from PNG provenances, Claudie River (northern Queensland), and the southernmost Queensland provenances, suggesting that the level of inbreeding depression is relatively uniform across these provenances. This is in spite of the major differences in genetic diversity and outcrossing rates among these provenances reported by BuTCHER et al. (1998, 1999). In other species, for example Eucalyptus grandis (HodGson, 1976), E. regnans (GRIFFIN and COTTERILL, 1988) and Pinus radiata (WU et al., 1997) the degree of inbreeding depression has been shown to differ among families. These other studies tested control-pollinated self and outcross progeny set out in purposedesigned trials, enabling better statistical testing of family-bycrossing status interaction than was possible in our study.

The level of inbreeding depression in A. mangium is consistent with that found in two other diploid, predominantly outcrossing species of Acacia, A. decurrens and A. mearnsii (MoFFATT and NIXON, 1974). Self-fertilization in both these species leads to the presence of numerous deleterious morphological characteristics in the population and a significant decrease in fertility and general vigour. In a field trial at Sweetwaters in South Africa, overall mean height of open-pollinated progeny of 13 families of $A$. decurrens at $2 \frac{3}{4}$ years was $7.3 \mathrm{~m}$, compared with $6.2 \mathrm{~m}$ for selfed progenies (produced by bagging flowering branches to exclude outcross pollen). For 12 families of $A$. mearnsii, the corresponding heights were $7.2 \mathrm{~m}$ for open-pollinated progenies and $5.3 \mathrm{~m}$ for selfed progenies. These levels of inbreeding depression are comparable to those reported here for A. mangium.

Comparison across orchards provides another confirmation of the importance of selfing in reducing early growth. Three of the orchards were developed from a very similar genetic base: Ba Vi Pongaki was developed from the Pongaki, PNG provenance, while Dong $\mathrm{Ha}$ and $\mathrm{Ba}$ Vi Fortip orchards were developed from a mix of PNG provenances plus about $30 \%$ representation of Claudie River, Queensland, which is the next best performing provenance after PNG (HARWOOD and WILLIAMS, 1992).
All three orchards had been selectively thinned to remove inferior trees, achieving a stand density of 300-400 stems per hectare at the time of seed harvesting. The twelve mother trees sampled in each orchard were spaced out across the orchard and chosen at random among those bearing seed crops. Given similar genetic origin and selective thinning, and a sample of twelve trees per orchard, one might expect the progeny from the three orchards to have very similar average performance. The Ba Vi Pongaki and Dong Ha orchards, with predominantly outcrossed progeny, displayed the fastest early height and diameter growth, while the Ba Vi Fortip orchard, with predominantly selfed progeny, displayed the slowest height growth at 18 months and the second-slowest diameter growth. The statistical comparison, albeit of low power, showed that the difference between these three orchards, attributable to the high level of selfing at Ba Vi Fortip, was significant.

The overall performance of the Phong Chau and Ham Yen orchards is also noteworthy. The Phong Chau orchard was established from a base of the Cardwell provenance (latitude $18^{\circ} \mathrm{S}$, in Queensland). While the exact provenance make-up of the Ham Yen orchard is not known, it is likely that it is based on the southernmost Queensland provenances (latitude $\left.15-18^{\circ} \mathrm{S}\right)$, as seed from the Claudie River provenance was not despatched to Vietnam until the late 1980s, after Ham Yen was planted (CSIRO Australian Tree Seed Centre, unpublished records). Thus, both orchards are probably based on Queensland natural provenances that exhibit low $(\sim 30 \%)$ rates of outcrossing in their native environment. Nevertheless, the two orchards comprised of these provenances gave outcrossing rates of over $90 \%$ in the northern Vietnam environment. In the field trial, the mean performance of their progeny was inferior to that of the two PNG-based orchards with high outcrossing rates. This is consistent with the provenance rankings obtained using natural-provenance seed (HARWOOD and WILLIAMS, 1991), showing that natural inbreeding in the southernmost provenances in Queensland is not the sole cause of their poorer performance. They appear to be intrinsically slower-growing than PNG and Claudie River provenances even after full outcrossing is achieved.

The high rate of selfing in the $\mathrm{Ba}$ Vi Fortip orchard is believed to have been caused by a low rate of flowering in this young orchard planted on an infertile site; only $18 \%$ of trees carried light seed crops at the time of crop sampling (BUTCHER et al., 2002), while at least $60 \%$ of trees had flowered to produce moderate or heavy seed crops in the Ba Vi Pongaki and Dong Ha orchards. The results of the field trial reported here, together with the flowering information from the orchards, suggest that seed crops collected from $A$. mangium orchards after light flowering are likely to perform poorly because of high levels of selfing.

In Vietnam (latitude $9^{\circ} \mathrm{N}$ to $23^{\circ} \mathrm{N}$ ), the reproductive phenology of $A$. mangium is strongly seasonal, with flowering occurring in the cooler, drier season in October-December and seed crops ripening in April-May. At equatorial latitudes $\left(5^{\circ} \mathrm{S}\right.$ to $5^{\circ} \mathrm{N}$ ), where seasonal variation in climate is much less, flowering of A. mangium occurs sporadically throughout the year, for example in Sabah, Malaysia (SEDGLey et al., 1992). This asynchronous flowering may lead to increased levels of selfing in seed production facilities, which may be a cause of observed poor performance of the resulting progeny (TURVEY, 1996; NiRSATMANTO et al., 2003). Investigation of outcrossing rates in seed orchards at equatorial latitudes is therefore warranted.

Rapid genetic deterioration has been documented in several unmanaged land races of tropical acacias. Volume production of the land races is less than half that of natural provenances in 
several cases, for example A. auriculiformis in Thailand (LUANGVIRIYASAENG and PinyoPUSARERK, 1998). Build-up of inbreeding through self-fertilization occurring in isolated trees or poorly-flowering stands used for seed collection over successive generations, and the associated depression of vigour that we have demonstrated in this study, could explain this phenomenon.

\section{Acknowledgments}

This study was funded in part by the Australian Agency for International Development, and the Australian Centre for International Agricultural Research. Additional financial and logistic support was provided by CSIRO Forestry and Forest Products, the Research Centre for Forest Tree Improvement, Forest Science Institute of Vietnam and the Agricultural Genetics Institute of Vietnam.

\section{References}

Butcher, P. A., Moran, G. F. and Perkins, H. D.: RFLP diversity in the nuclear genome of Acacia mangium. Heredity 81: 205-213 (1998). Butcher, P. A., Glaubitz, J. C. and Moran, G. F.: Applications for microsatellite markers in the domestication and conservation of forest trees. Forest Genetic Resources Information 27: 34-42 (1999). Butcher, P. A., Decroocq, S., Gray, Y. and Moran, G. F.: Development, inheritance and cross-species amplification of microsatellite markers from Acacia mangium. Theoretical and Applied Genetics 101 1282-1290 (2000). - Butcher, P. A., Harwood, C. E. and Tran Ho QUANG: Studies of mating systems in seed stands suggest possible causes of variable outcrossing rates in natural populations of Acacia mangium. IUFRO Symposium 'Population and Evolutionary Genetics of Forest Trees'. Stará Lesná, Slovakia, August 25-29, 2002 (2002) Eldridge, K. G., Davidson, J., Harwood, C. E. and Van WyK, G.: Eucalypt Domestication and Breeding. Oxford University Press (1993). GRIFFIN, A. R. and CotTeRILL, P. P.: Genetic variation in growth of outcrossed, selfed and open-pollinated progenies of Eucalyptus regnans and some implications for breeding strategy. Silvae Genetica 37: 124-131 (1988). - Harwood, C. E. and Williams, E. R.: A review of provenance variation in the growth of Acacia mangium. Pp. 22-30 in CARRON, L. T. and AkEN, K. eds.: Breeding Technologies for Tropical Acacias. ACIAR Proceedings No. 37. Canberra: ACIAR (1992). — HoDGSON, L. M.: Some aspects of flowering and reproductive behaviour of Eucalyptus grandis (Hill) Maiden at J.D.M. Keet Research Station 2. The fruit, seed, seedlings, self-fertility, selfing and inbreeding effects. South African Forestry Journal 98: 32-43 (1976). — LuANGVIRIYASAENG, L. and PinYoPUSARERK, K: Genetic variation in a second-generation progeny trial of Acacia auriculiformis in Thailand. Journal of Tropical Forest Science 14: 131-144 (2001). - MoffatT, A. A. and Nixon, K. M.: The effects of self-fertilization on green wattle (Acacia decurrens Willd.) and black wattle (Acacia mearnsii De Wild.). Pp 66-84 Report for 1973 to 1974 Wattle Research Institute of South Africa (1974). - MuONA, O., MoRAN, G. F. and BELL, J. C.: Hierarchical patterns of correlated mating in Acacia melanoxylon. Genetics 127: 619-626 (1991). - NiRSATMANTO, A. KuRINOBU, S. and HaRdiYANTO, E. B.: A projected increase in stand volume of introduced provenances of Acacia mangium in seedling seed orchards in south Sumatra, Indonesia. Journal of Forest Research 8 127-131 (2003). - SEDGley, M. and HARBARD, J.: Pollen storage and breeding system in relation to controlled pollination of four species of Acacia (Leguminosae: Mimosoideae). Australian Journal of Botany 41 : 601-609 (1993). - Sedgley, M., Wong Chin Yong, Newman, V., HarBARD, J. Smith, R., KoH KIAN GHAN and TAJUdDin, A.: Phenology of Acacia mangium and A. auriculiformis in Australia and Malaysia. Pp. 36-44 in CARRON, L. T. and AKEN, K. eds.: Breeding Technologies for Tropical Acacias. ACIAR Proceedings No. 37. Canberra, ACIAR (1992). - Sim Boon Liang: The genetic base of Acacia mangium Willd. in Sabah. Pp 597-603 in Barnes, R. D. and Gibson, G. L. eds.: Provenance and Genetic Improvement Strategies in Tropical Forest Trees. Oxford: Commonwealth Forestry Institute (1984). - TuRnbull, J. W., Midgley S. J. and Cossalter, C.: Tropical acacias planted in Asia: an overview. Pp. 14-28 in Turnbull, J. W., Crompton, H. and Pinyopusarerk, K.: Recent Developments in Acacia Planting. ACIAR Proceedings No. 82. Canberra: ACIAR (1998). - TURVEY, N. D.: Growth at age 30 months of Acacia and Eucalyptus species planted in Imperata grasslands in Kalimantan Selatan, Indonesia. Forest Ecology and Management 82 185-195 (1996). - Wang Tongli, Hagqvist, R., Tigerstedt, P. M. A and WANG, T. L.: Inbreeding depression in three generations of selfed families of silver birch (Betula pendula). Canadian Journal of Forest Research 29: 662-668 (1999). - Williams, C. G. and SAvolainen, O. Inbreeding depression in conifers: implications for breeding strategy. Forest Science 42:102-117 (1996). - Wu, H. X., Matheson, A. C. and SPENCER, D.: Inbreeding in Pinus radiata. 1. The effect of inbreeding on growth, survival and variance. Theoretical and Applied Genetics 97: 1256-1268 (1997).

\title{
A Report of Triploid Populus of the Section Aigeiros
}

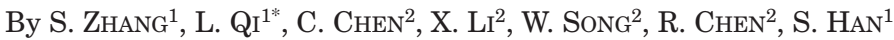

(Received $6^{\text {th }}$ March 2004)

\begin{abstract}
This screening study analyzed ploidy levels by counting the chromosome number of 61 Aigeiros cultivars grown in China. Triploid Aigeiros has been found in four of these cultivars: Populus $\mathrm{x}$ euramericana (Dode) Guiner cv. Wuhei-1, P. x Liaoheni$c a$, P. Langfangensis-3 Wang ( $P$. deltodide Barry cv. "Shan-

\footnotetext{
$\overline{{ }^{1} \text { Laboratory }}$ of Cell Biology, The Research Institute of Forestry, The Chinese Academy of Forestry, Beijing 100091, P. R. China.

${ }^{2}$ College of Life Sciences, Nankai University, Tianjin 300071, P. R. China.

* Corresponding author: LIWANG QI, Laboratory of Cell Biology, The Research Institute of Forestry, The Chinese Academy of Forestry, Beijing 100091, P. R. China. Telephone: 86-10-62888445, Fax: 86-10-62872015, E-mail: lwqi@caf.ac.cn
}

haiguan" $\times P$. simonii $\times$ P. pyramidalis $-12+$ Ulmus pumila Linn.), and P. x euramericana (Dode) Guinier. cv. "Zhonglin-46". The karyotype analysis indicates that triploid Aigeiros might be derived from original allotriploid. Because growth of the triploid trees was faster than their respective diploid hybrids or clones in the plantations where we collected the materials, we expect that they will play a significant role in breeding, reforestation and fiber production in China.

Key words: Aigeiros, triploid.

\section{Introduction}

The genus Populus is widely distributed and cultivated in the world. More than 20 million hectares of natural forests occur across the world, of which about three million hectares 